\title{
Axillary Lymph Node Dissection Extension in Breast Cancer Between Under and Overtreatment Analysis of a series of cases and literature review
}

\author{
DANIEL ION ${ }^{1,2}$, ALEXANDRA BOLOCAN ${ }^{1,2 *}$, BOGDAN SOCEA ${ }^{2,3}$, OCTAVIAN ANDRONIC $^{1,2}$, GEORGIANA RADU ${ }^{2}$, \\ DAN NICOLAE PADURARU1,2 \\ IUniversity Emergency Hospital Bucharest, 3 ${ }^{\text {rd }}$ General Surgery Clinic, 169 Splaiul Independentei, 050098, Bucharest, \\ Romania \\ ${ }^{2}$ Carol Davila University of Medicine and Pharmacy, 37 Dionisie Lupu Str., 020021, Bucharest, Romania \\ ${ }^{3}$ Sf. Pantelimon Emergency Clinical Hospital, 340-342 Pantelimon Road, 021659, Bucharest, Romania
}

The surgical management of breast cancer tumors depends not only on knowing the right histological type of tumor, but also on identifying the grade of axillary node invasion and the presence of metastases. Unfortunately, due to a lack of general understanding of how these tumors actually spread and their path towards axillarylymph nodes, there is a tendency of over or undertreating patients in the surgical environment. Even though we now have the Sentinel Ganglion method to help us, we haven't decided on a universally accepted algorithm in the management of this disease. Many studies are still needed in order to fully clarify the most appropriate surgical management for each type of tumor and the level of axillary node dissection. Multiple factors should be taken into account when managing the case of a patient suffering from breast cancer and faced with the need of an axillarylymph node dissection (ALND). We have tried to identify some of these factors based on the experience of our clinic and available literature. The factors identified are the positive SLN (Sentinel Lymphatic Node) aspect, the differentiation between micro and macrometastases, the use of the S classification of SLN and microanatomic location of SLN metastases and the microanatomic location (MAL) of the tumor deposit in the sentinel ganglion.

Keywords: sentinel node biopsy, axillary lymph node dissection, early breast cancer, node metastasis, sentinel node

Along with the size of the tumor, the status of the axillary lymph nodes is a basic element in the staging and prognosis of breast cancer. If the first parameter can be evaluated relatively simply both clinically and imagistically, when talking about the axilla the evaluation is more complex even after the introduction of the sentinel ganglion technique. The simple equation Positive Sentinel Ganglion $=$ Complete ALND has been discussed by numerous studies with multiple adjustments and nuances to center the surgical indication as accurately as possible without ever reaching a universally accepted algorithm [1-3] .

Hormonal contraception increases the risk of breast cancer [4] and coexistence with ovarian cancer can be present [5].

Our retrospective study aims to analyze the accuracy of full ALND (Axillary Lymph Node Dissection) indication in early breast cancer patients in order to avoid the two extremes: under and over surgical treatment of the axilla.

\section{Experimental part}

\section{Materials and methods}

We present a retrospective, descriptive, unicentric study carried out between the $1^{\text {st }}$ of $J$ anuary 2017 and the $31^{\text {st }}$ of December 2017 in the 3rd General and Emergency Surgical Section from the Emergency University Hospital Bucharest, Romania which comprises 53 cases.

The main objective was to confront the histological examination of the ALND with the preoperative evaluation of the lymph node and their degree of overlapping.

Inclusion criteria:

- Patients with breast cancer for whom mastectomy and partial / total ALND were practiced

$$
\text { - Stage IIA (T2NOMO / T1N1MO), IIB (T2N1MO / T3NOMO), }
$$$$
\text { IIIA (T3N1M0) and IIIB (T4N1M0) }
$$

- The presence of all necessary information in the HP (histopathology) result papers

Exclusion criteria:

- Stage IV

- Conservative surgical management of the breast

The consultation of available literature was conducted using the PubMed, Scopus and WoS platforms using the following keywords: santinel node biopsy and axillary lymph node dissection, with filtering of the results according to the year of publication (more recent than 2000) and the availability of in extenso articles in English.

We have used the following acronyms and definitions: SLN (Sentinel lymphatic node); SLN positive (SLN invaded by tumor cells); ALND (Axillary Lymph Node Dissection); complete ALND - excision of lymph nodes stations I, II and III; partially ALND - excision only of I, II stations; positive ALND (invaded axillary nodes identified); negative ALND (no invaded axillarynode identified); MAL (microanatomic location).

\section{Results and discussions}

The evaluation of the studied group of patients revealed an age distribution between 28-87 years with an average of 59.01 years (fig. 1).

Out of 53 patients in the whole lot, 25 had partial ALND $(47.2 \%)$ with a $44 \%$ rate of positivity and the other 28 had complete ALND (52.8\%) with a $53.76 \%$ rate of positivity (table 1).

The distribution of neoplastic disease based on TNM staging relative to the ALND positivity (detailed in table 2 and fig. 2) revealed a downward overtreatment rate from $80 \%$ in Stage IIA to $37.5 \%$ in Stage IIIB. At the same time, the degree of differentiation was a parameter correlated with the rate of positivity grow ing from $30 \%$ in the G1 stage to $73.3 \%$ in $\mathrm{G} 3$ (fig. 3). 


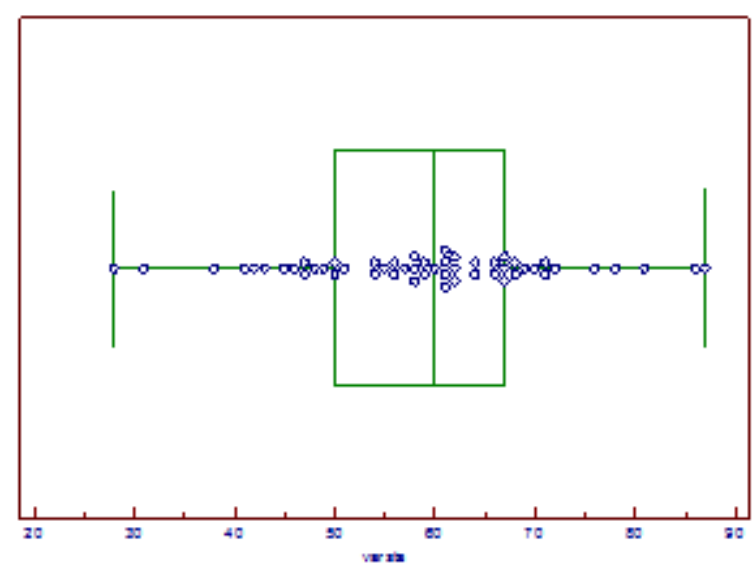

Fig. 1. Statistical data about the patients' age

Table 1

THE PATIENTS' DISTRIBUTION BY THE TYPE OF ALND AND THE PRESENCE OF INVASION

\begin{tabular}{|l|l|l|l|}
\hline \multicolumn{3}{|l|}{ Invasion } & \\
\hline ALND & Positive & Negative & \\
\hline Partial & 11 & 14 & $25(47.2 \%)$ \\
\hline Complete & 15 & 13 & $28(52.8 \%)$ \\
\hline & $26(49.1 \%)$ & $27(50.9 \%)$ & 53 \\
& & & \\
\hline
\end{tabular}

Table 2

THE PATIENTS' DISTRIBUTION BASED ON THE STAGE OF THE DISEASE AND THE PRESENCE OF INVASION

\begin{tabular}{|c|c|c|c|c|c|}
\hline & \multicolumn{4}{|c|}{ TNM Stage } & \\
\hline ALND & IIA & IIB & IIIA & IIIB & \\
\hline Negative & 4 & 3 & 13 & 6 & $26(49.1 \%)$ \\
\hline Positive & 1 & 2 & 14 & 10 & $27(50.9 \%)$ \\
\hline & $\begin{array}{l}5 \\
(9.4 \%)\end{array}$ & $\begin{array}{l}5 \\
(9.4 \%)\end{array}$ & $\begin{array}{l}27 \\
(50.9 \%)\end{array}$ & $\begin{array}{l}16 \\
(30.2 \%)\end{array}$ & 53 \\
\hline
\end{tabular}

For patients in whom an axillary node invasion has been proven, an average number of 4.6 invaded ganglions were identified. The number of invaded nodes in relation to the stage (table 3) has highlighted a smaller average value in patients with a IIIB stage when compared to patients with a IIIA stage. highest positivity rate in the studied lot was identified in the group of patients with ER+PR+HER (table 4).

Most patients with positive SLN in early-stage breast cancer have no additional metastasis in non-SLN, as proven by the ALND $[3,6]$. These patients are at risk of morbidity from excessive axillary dissection, without any benefit in what concerns the survival rate.

Despite numerous studies on the issue, discussions on the most rigorous selection criteria to reduce unnecessary ALND still persist [7].

Even in the case of SLN, the non-SLN positive frequency does not exceed $1 / 3$ in some studies [8-10]. The rest, i.e. almost $2 / 3$, the ganglia located beyond the sentinel group are not invaded, so they should not be removed. The question arises whether there is a factor or a group of
In what concerns the immunohistochemical profile, the

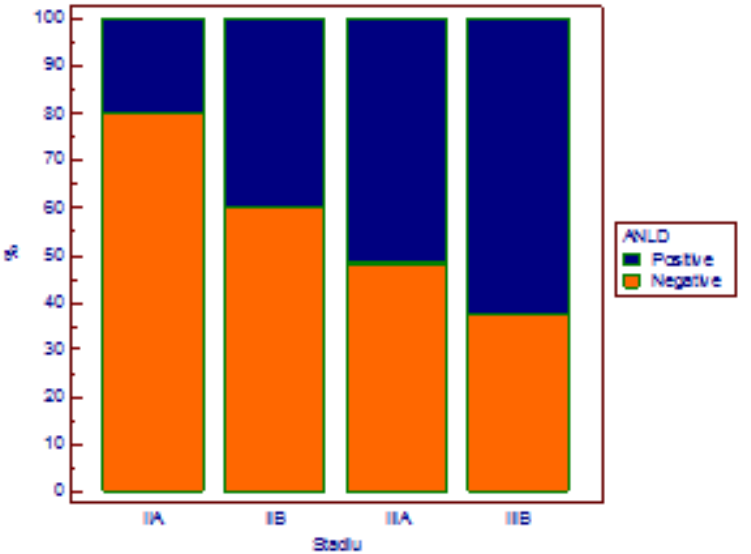

Fig. 2.The patients' distribution based on the stage of the disease and the presence of invasion

Table 3

STATISTICAL DATA REGARDING THE NUMBER OF INVADED GANGLIONSIN PATIENTS WITH POSITIVE ALND

\begin{tabular}{|l|l|l|l|l|}
\cline { 1 - 2 } & $\begin{array}{l}\text { Invaded } \\
\text { nodes }\end{array}$ & \multicolumn{5}{|l}{} \\
\hline Stage & IIA & IIB & IIIA & IIIB \\
\hline N & 1 & 2 & 14 & 10 \\
\hline Mean & 2,000 & 5,500 & 6,143 & 4,500 \\
\hline Median & 2,000 & 5,500 & 5,500 & 3,500 \\
\hline Minimum & 2,000 & 4,000 & 2,000 & 2,000 \\
\hline Maximum & 2,000 & 7,000 & 12,000 & 9,000 \\
\hline
\end{tabular}

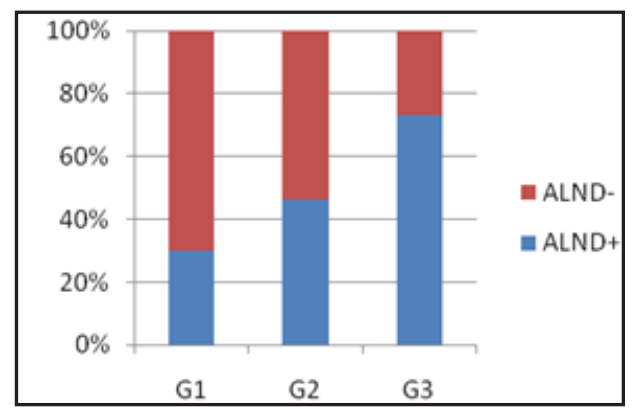

Fig. 3. Patient distribution according to the stage of the neoplastic disease and the presence of invasion

quantifiable factors that could help nuance the indication of ALND so as to minimize axilla overtreatment [11-13].

The first of these factors was the positive SLN aspect: the presence of two macrometastases in patients programmed for breast conservative surgery, in which the entire breast irradiation and systemic adjuvant treatment were mandatory, requires ALND [14].

A second factor is the differentiation between micro and macrometastases [15-18]. A cancer cell depot must contain more than 200 cells or a size of at least $0.2 \mathrm{~mm}$ to modify stage N. Otherwise, even if it does not alter the $\mathrm{N}$ stage, it also attracts the addition of an abbreviation ( $i+$ <isolated tumor cell>for a small number of immunohistochemically identified cells, $\mathrm{mol}+$ when cells cannotbe visualized butare identified by RT-PCR) to identify how the invasion is highlighted. The scattering range of cancer cells ranging from $0.2 \mathrm{~mm}$ to $2 \mathrm{~mm}$ defines the micrometastasis. Any area greater than $2 \mathrm{~mm}$ defines macrometastasis and changes the $\mathrm{N}$ stage [19-21].

The third factor is the use of the S classification of SLN and microanatomic location of SLN metastases. The $S$ classification uses the maximum depth of metastatic invasion measured from the inner layer of the capsule to the tumor cell mass. Based on this distance, 3 stages are REV.CHIM.(Bucharest) $70 \bullet$ No. $2 \bullet 2019$ 
Table 4

PATIENT DISTRIBUTION ACCORDING TO IMMUNOHISTOCHEMICAL PROFILE AND THE PRESENCE OF INVASION

\begin{tabular}{|c|c|c|c|c|c|c|}
\hline & \multicolumn{5}{|c|}{ IMMUNOHISTOCHEMICAL PROFILE } & \\
\hline ALND & $\begin{array}{l}\text { ER-PR- } \\
\text { HER- }\end{array}$ & $\begin{array}{l}\text { ER+PR- } \\
\text { HER- }\end{array}$ & $\begin{array}{l}\text { ER-PR+ } \\
\text { HER- }\end{array}$ & $\begin{array}{l}\mathrm{ER}+\mathrm{PR}+\mathrm{HE} \\
\mathrm{R}-\end{array}$ & $\begin{array}{l}\text { ER+PR+ } \\
\text { HER+ }\end{array}$ & \\
\hline NEGATIVE & 6 & 2 & 0 & 5 & 13 & $26(49.1 \%)$ \\
\hline POSITIVE & 8 & 0 & 1 & 9 & 9 & $27(50.9 \%)$ \\
\hline & $\begin{array}{l}14 \\
(26.4 \%)\end{array}$ & $\begin{array}{l}2 \\
(3.8 \%)\end{array}$ & $\begin{array}{l}1 \\
(1.9 \%)\end{array}$ & $\begin{array}{l}14 \\
(26.4 \%)\end{array}$ & $\begin{array}{l}22 \\
(41.5 \%)\end{array}$ & 53 \\
\hline
\end{tabular}

defined: $\mathrm{SI} \leq 0.3 \mathrm{~mm}$, SII 0.31-1mm and SIII> $1 \mathrm{~mm}$. Patients with only subcapsular SLN metastasis (SI) have the lowest risk of metastasis in nonSLNs, being therefore included in the category where ALND is not indicated. This reduces the batch of overtreatment according to classical criteria [9].

The fourth factor is the microanatomic location (MAL) of the tumor deposit in the sentinel ganglion. Tumor deposits are mapped inside the SLN having a prognostic value relative to location. From the combination of the possible mapping variants into the ganglion, 5 categories are shown: only subcapsular, parenchymal, subcapsular and parenchymal, multifocal metastatic disease and extended metastatic disease, including extracapsular invasion [22].

Furthermore, studies have shown that the apparition of lymph nodes recurrences is not related to the occurrence of distant metastases, and that they can be identified previously, simultaneously or afterwards [23-28]. The evolution in terms of survival and the occurrence of local recurrences in breast cancer patients who were treated with ALND did not show any significant differences from those with SNB alone, regardless of their positivity [29-31]. The associated comorbidities may play a role in the final prognosis [32-36].

Breast tumors can be divided according to their histological forms into favorable (tubular, mucinous and papillary), and aggressive (comedo, inflammatory), as well as according to the $\mathrm{G} 1, \mathrm{G} 2$ and $\mathrm{G} 3$ grading. Framing the tumor through a biopsy into these categories can weight in the decision regarding the ALND indication and extension - partial or complete.

\section{Conclusions}

To conclude, we have drawn the following final ideas from the study and literature review:

Surgery of the axilla in breast cancer is of value in both staging and the therapeutic management. Establishing the degree of extension of nerve courage has been made over the last decades on the basis of questionable criteria in which positive SLN occupied the central site but led to an unacceptable percentage of cases of overtreatment.

Partial ALND and qualitative extemporaneous HP outcome by adopting the SClassification and MAL requires time and cooperation, but can reduce the number of completely abusive ALNDs.

A periodic review of HP results after ALND and the reassessment of the opportunity for ALND for each case helps improving the indication [37].

The temptation of the extension of the surgical gesture exists and follows a certain routine and even a general resistance to the paradigm changes.

\section{References}

1. ROSEN, P.P, SAIGO, P.E., BRAUN, D.W., WEATHERS, E., FRACCHIA, A.A., KINNE, D.W., Ann. Surg., 194, no. 5, 1981, pp. 585-591.

2. PARASCHIV, B., TOMA, C.L., DIACONU, C.C., Archivos de Bronconeumología, 49, no. 7, 2013, pp. 315-316.

3.STEELE, R.J .C, FORREST, A.P.M., GIBSON, T, STEWART, H.J , CHETTY, U., Br. J. Surg., 72, no. 5, 1985, pp. 368-369.

4. IONESCU, C., NAVOLAN, D., CALIN, A., etal., Rev Chim (Bucharest), 69, no. 2, 2018, p. 478-483.

5. IONESCU, C.A., VLADAREANU, S., PLES, L., DIMITRIU, M.C.T., FURAU, G.O., VLADESCU, T.C., CALIN, A.M., OPRESCU, N.D., Romanian Journal of Morphology and Embriology, 58, no. 1, 2017, pp. 219-223. 6.BALACEANU, A., DIACONU, C., ARON, G., Medical Ultrasonography, 16, no. 2, 2014, pp. 172-174.

7. JULIAN, T.B., ANDERSON, S.J, KRAG, D.N., HARLOW, S.P., COSTANTINO, J.P., ASHIKAGA, T., WEAVER, D.L., MAMOUNAS, E.P., WOLMARK, N., J. Clin. Oncol., 31, no. 15_suppl, 2013, p. 1000.

8.LYMAN, G.H., SOMERFIELD, M.R., BOSSERMAN, L.D., PERKINS, C.L., WEAVER, D.L., GIULIANO, A.E., J. Clin. Oncol., 35, no. 5, 2017, pp. 561-564.

9. FINK, A.M., WONDRATSCH, H., LASS, H., JANAUER, M., SEVELDA, P., SALZER, H., JURECKA, W., ULRICH, W., CHOTT, A., STEINER, A., Ann. Surg. Oncol., 18, no. 6, 2011, pp. 1691-1697.

10.FLEISSIG, A., FALLOWFIELD, L.J ., LANGRIDGE, C.I., JOHNSON, L., NEW COMBE, R.G., DIXON, J.M., KISSIN, M., MANSEL, R.E., Breast Cancer Res. Treat., 95, no. 3, 2006, pp. 279-293.

11.DIACONU, C.,NASTASA, A., ZAKI, A.R., ARSALAN, M. The 2nd International Conference on Interdisciplinary Management of Diabetes Mellitus and its Complications - Diabetes mellitus as cardiovascular disease, INTERDIAB 2016 Proceedings, 2016, pp. 201-210. Ed. Niculescu. Editors Cristian Serafinceanu, Octavian Negoita, Viviana Elian.

12. GINGHINA, O., NEGREI, C., HUDITA, A., IOANA-LAVRIC, V., GALATEANU, B., DRAGOMIR, S., BURCEA DRAGOMIROIU, G.T.A., BARCA, M., NITIPIR, C., DIACONU, C.C., PANTEA STOIAN, A.M., IORDACHE, N., BALANESCU, A., Farmacia, 65, no. 6, 2017, pp. 947953.

13.CIUHU, A.N., RAHNEA NITA, R.A., POPESCU, M., DUMITRU BADIU, C.D., PANTEA STOIAN, A.M., LUPULIASA, D., GHERGHICEANU, F., DIACONU, C.C., RAHNEA NITA, G., Farmacia, 65, no. 2, 2017, pp. 173178.

14.MANSEL, R.E., FALLOWFIELD, L., KISSIN, M., GOYAL, A., NEWCOMBE, R.G., DIXON, J.M., YIANGOU, C., HORGAN, K., BUNDRED, N., MONYPENNY, I., ENGLAND, D., SIBBERING, M., ABDULLAH, T.I., BARR, L., CHETTY, U., SINNETT, D.H., FLEISSIG, A., CLARKE, D., ELL, P.J ., J NCl J. Natl. Cancer Inst., 98, no. 9, 2006, pp. 599-609.

15.MARCU, R.D., SPINU, A.D., SOCEA, B., BODEAN, M.O., DIACONU, C.C., VASILESCU, F., NEAGU, T.P., BRATU, O.G., Rev Chim (Bucharest), 69, no. 4, 2018, pp. 823-830.

16.BRATU, O.G., MARCU, R.D., SOCEA, B., NEAGU, T.P., DIACONU, C.C., SCARNECIU, I., TURCU, F.L., RADAVOI, G.D., BRATILA, E., BERCEANU, C., SPINU, A.D., Rev Chim (Bucharest), 69, no. 7, 2018, pp. 1813-1816. 
17.STANIMIR, M., CHIUTU, L.C., WESE, S., MILULESCU, A., NEMES, R.N., BRATU, O.G., Rom J Morphol Embryol, 57, no. 2 (suppl), pp. 849-852.

18.TATARU, A.L. , FURAU, G., AFILON, J., IONESCU, C., DIMITRIU, M., BRATU, O.G., TIT, D.M., BUNGAU, S., FURAU, C., J. Clin. Med., 8, no. 1, 2019, pp. E96; https://doi.org/10.3390/jcm8010096.

19.POHLODEK, K., BOZIKOVA, S., MECIAROVA, I., MUCHA, V., BARTOVA, M., ONDRIAS, F., Neoplasma, 63, no. 3, 2016, pp. 427-434. 20.ECANOW, J.S., ABE, H., NEWSTEAD, G.M., ECANOW, D.B., JESKE, J.M., RadioGraphics, 33, no. 6, 2013, pp. 1589-1612.

21.DIACONU, C.C., ARSENE, D., PARASCHIV, B., BALACEANU, A. BARTOS, D., Acta Endocrinologica, IX, no. 4, 2013, pp.637-642.

22.HUMPHREY, K.L., SAKSENA, M.A., FREER, P.E., SMITH, B.L., RAFFERTY, E.A., Radiographics, 34, no. 7, 2014, pp. 1807-16. 23.DEWAR, D.J ., NEWELL, B., GREEN, M.A., TOPPING, A.P., POWELL, B.W.E.M., COOK, M.G., J. Clin. Oncol., 22, no. 16, 2004, pp. 33453349.

24.GERVASONI, J.E, TANEJA, C., CHUNG, M.A., CADY, B., Surg. Clin. North Am., 80, no. 6, 2000, pp. 1631-1673.

25.DIACONU, C.C., ARSENE, D., BALACEANU, A., BARTOS, D., Romanian Journal of Morphology and Embryology, 55, no. 3, 2014, pp. 973-976.

26.SOCEA, L.I., VISAN, D.C., BARBUCEANU, S.F., APOSTOL, T.V., BRATU, O.G., SOCEA, B., Rev Chim (Bucharest), 69, no. 4, 2018,

p. $795-797$

27.MEHEDINTU, C., ANTONOVICI, M., BRINDUSE, L., BRATILA, E., STANCULESCU, R., BERCEANU, C., BRATU, O., PITURU, S. ONOFRIESCU, M., MATASARIU, D.R., Rev Chim (Bucharest), 69, no. 3, 2018, p. 581-584.
28.PAHONTU, E., SOCEA, L.I., BARBUCEANU, S.F., ILIES, D.C., BADEA, M., OLARU, O.T., GULEA, A., SOCEA, B., BRATU, O.G., Rev Chim (Bucharest), 69, no. 11, 2018, p. 2959-2963.

29.GERVASONI, J.E., SBAYI, S., CADY, B., Ann. Surg. Oncol., 14, no. 9, 2007, pp. 2443-2462.

30.HWANG, R.F., GONZALEZ-ANGULO, A.M., YI, M., BUCHHOLZ, T.A., MERIC-BERNSTAM, F., KUERER, H.M., BABIERA, G.V., TEREFFE, W., LIU, D.D., HUNT, K.K., Cancer, 110, no. 4, 2007, pp. 723-730.

31.GUENTHER, J.M., HANSEN, N.M., DIFRONZO, L.A., GIULIANO, A.E., COLLINS, J.C., GRUBE, B.L., O'CONNELL, T.X., Arch Surg, 138, no. 1, 2003, pp. 52-56.

32.DIACONU, C.C., DRAGOI, C.M., BRATU, O.G., NEAGU, T.P., PANTEA STOIAN, A., COBELSCHI, P.C., NICOLAE, A.C., IANCU, M.A., HAINAROSIE, R., STANESCU, A.M.A., SOCEA, B., Farmacia, 66, no. 3, 2018, pp. 408-415.

33.DIACONU, C.C., MANEA, M., IANCU, M.A., STANESCU, A.M.A., SOCEA, B., SPINU, D.A., MARCU, D., BRATU, O.G., Rev Chim (Bucharest), 69, no. 5, 2018, p. 1071-1074.

34.DIACONU, C.C., STANESCU, A.M.A., PANTEA STOIAN, A., TINCU, R.C., COBILINSCHI, C., DRAGOMIRESCU, R.I.F., SOCEA, B., SPINU, D.A., MARCU, D., SOCEA, L.I., BRATU, O.G., Rev Chim (Bucharest), 69, no. 6, 2018, p. 1367-1370.

35.MANEA, M., MARCU, D., PANTEA STOIAN, A., GAMAN, M.A., GAMAN, A.M., SOCEA, B., NEAGU, T.P., STANESCU, A.M.A., BRATU, O.G., DIACONU, C.C., Rev Chim (Bucharest), 69, no. 11, 2018, p. 4180-4184. 36.RADULESCU, D., BALCANGIU STROESCU, A., PRICOP, C., GEAVLETE, B., NEGREI, C., BRATU, O., GINGHINA, O., VACAROIU, I., Rev Chim (Bucharest), 68, no. 1, 2017, p. 52-54.

37.BALACEANU, A., DIACONU, C., MATEESCU, D., STANICA, A., Medical Ultrasonography, 12, no. 4, 2010, pp. 345-348.

Manuscript received: 16.07 .2018 